\title{
Pottery from 41NA202: The Stephens Site in Nacogdoches County, Texas
}

Robert L. Turner Jr. Unknown

Follow this and additional works at: https://scholarworks.sfasu.edu/ita

Part of the American Material Culture Commons, Archaeological Anthropology Commons, Environmental Studies Commons, Other American Studies Commons, Other Arts and Humanities Commons, Other History of Art, Architecture, and Archaeology Commons, and the United States History Commons

Tell us how this article helped you.

This Article is brought to you for free and open access by the Center for Regional Heritage Research at SFA ScholarWorks. It has been accepted for inclusion in Index of Texas Archaeology: Open Access Gray Literature from the Lone Star State by an authorized editor of SFA ScholarWorks. For more information, please contact cdsscholarworks@sfasu.edu. 


\section{Pottery from 41NA202: The Stephens Site in Nacogdoches County, Texas}

Creative Commons License

(c) (i) (9)

This work is licensed under a Creative Commons Attribution-NonCommercial 4.0 International License 


\title{
Pottery from 41NA202: The Stephens Site in Nacogdoches County, Texas
}

\author{
Robert L. Turner, Jr.
}

\begin{abstract}
INTRODUCTION
In late 1940 and early 1941, my father and I excavated the Stephens site (41NA202). The site is located on Bailey Creek approximately $5 \mathrm{~km}$ west of Central Heights in Nacogdoches County. The site had been identified by the land owner, who gave my father permission to excavale.

The purpose of this short article is to briefly describe the ceramic assemblage from the site. The assemblage is unique for this area of East Texas.

The excavated area from which the ceramic artifacts were recovered measured approximately 3 $x 4.6 \mathrm{~m}$ with the long axis along the plow rows. The site was about $6 \mathrm{~m}$ north of the then stream bed and consisted of a scatter of European trade beads within the soil as well as numerous sherds of Caddo Indian manufacture. The area was excavated to the underlying clay, which was no more than $25 \mathrm{~cm}$ or so below the surface, and the dirt was water screened in order to recover the artifacts. These artifacts consisted of European glass trade beads (more than 7420 beads of 21 different varieties) and ceramic sherds of Indian pottery. Other than two silver beads, no metal artifacts were found. Our conclusion concerning the site was that it resulted from at least one shallow grave of an individual that had been plowed up and the grave offerings scattered from the yearly cultivation of the area. One small skull fragment was the only trace of human remains.
\end{abstract}

\section{CERAMIC VESSELS AND SHERDS}

The small rimless bowl is a Natchitoches Engraved vessel (Figure 1). The temper is shell, it is orange brown in color, and the design of scrolls and tick marks is perfectly consistent with the type description.

The second vessel is a small undecorated bowl with shell temper and a smoothed hard orange-tan

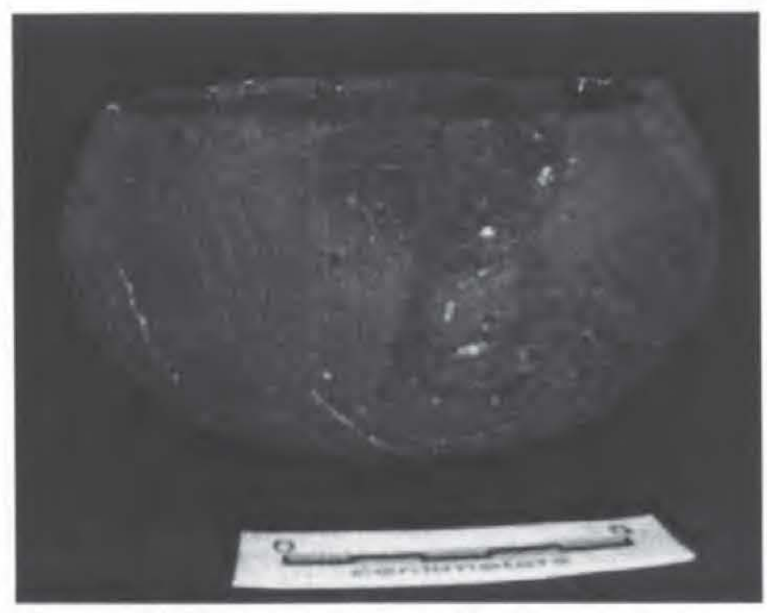

Figure 1. Natchitoches Engraved bowl from the Stephens site.

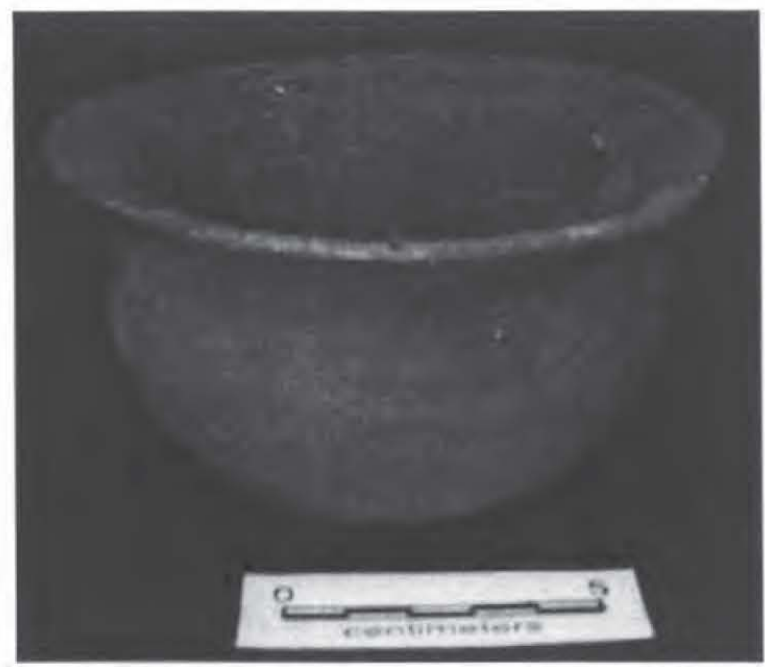

Figure 2. Small undecorated shell-tempered bowl.

surface (Figure 2). There are also three tan to graycolored globular-bodied plain bottles, also shelltempered (Figure 3). One bottle neck sherd that fits the middle bottle defines a short neck no more than $1.5 \mathrm{~cm}$ from the body to the lip.

Another seven sherds, among them one rim, are also from a Natchitoches Engraved shell-tempered 


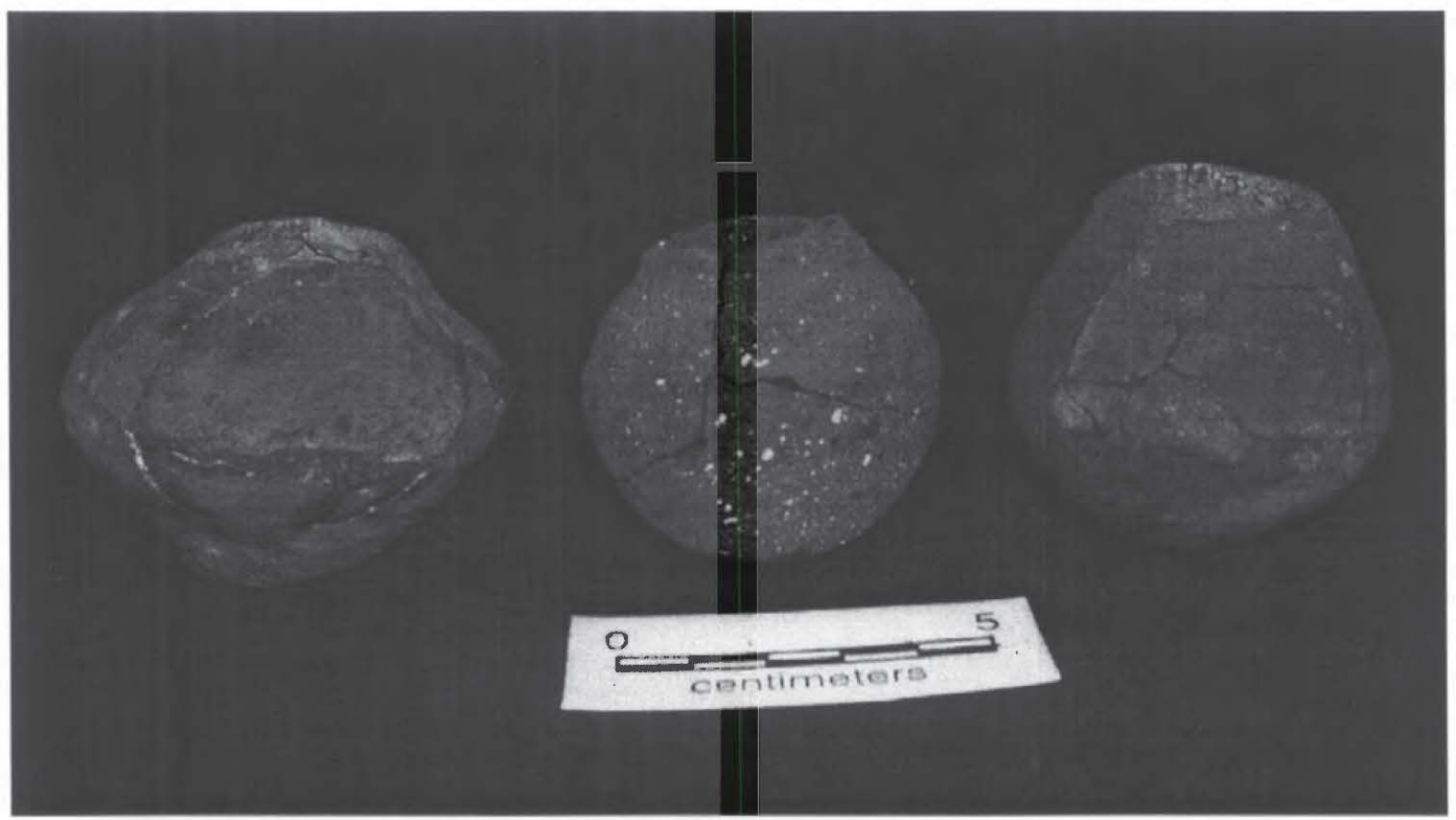

Figure 3. Three plain shell-tempered bottles.

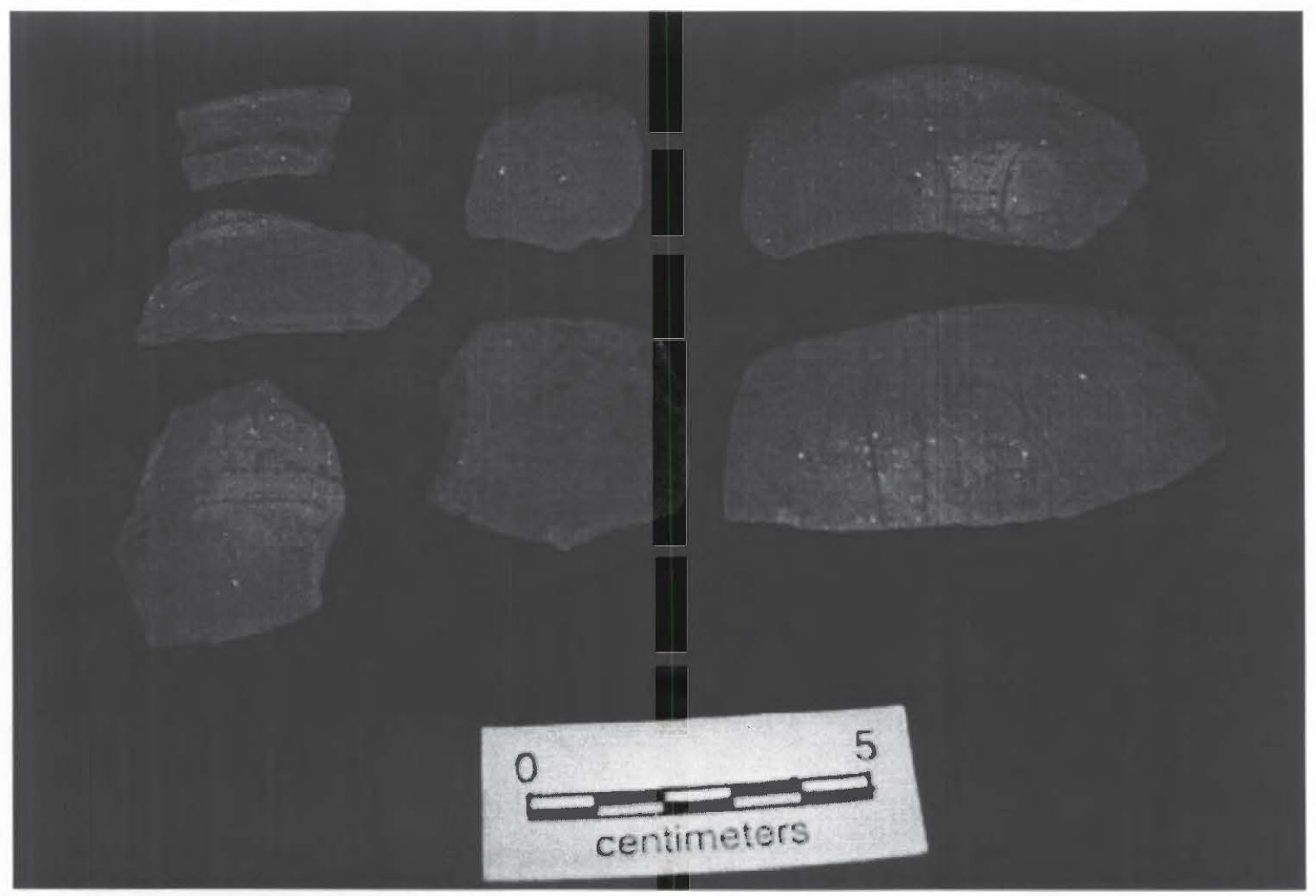

Figure 4. Sherds from a Natchitoches Engraved vessel from the Stephens site. 
bowl (Figure 4). Finally, there is another group of 29 sherds (not illustrated) that are shell-tempered, and gray to tan in color, like the Natchitoches Engraved vessels. The design features bands of various widths of ladder-like elements and single lines parallel to the ladder elements. The ceramic type is unknown.

There is also a group of 27 small sherds that include shell-tempered and non-shell-tempered wares. Three appear to be from a small bottle. None appear to be from the previously described vessels or sherd groups.

\section{CONCLUSION}

I am writing a paper on the Stephens site and determining when this burial occurred in time, if possible. For those interested in Caddo ccramics from the historic era, they should now be aware of this displaced cluster of shell-tempered Natchitoches Engraved vessels in Nacogdoches, Texas. 